\title{
Effects of a single intraperitoneal administration of cadmium on femoral bone structure in male rats
}

\author{
Monika Martiniaková ${ }^{1 *}$, Hana Chovancová ${ }^{1 \dagger}$, Radoslav Omelka ${ }^{2 \dagger}$, Birgit Grosskopf ${ }^{3 \dagger}$ and Róbert Toman ${ }^{4 \dagger}$
}

\begin{abstract}
Background: Exposure to cadmium $(\mathrm{Cd})$ is considered a risk factor for various bone diseases in humans and experimental animals. This study investigated the acute effects of $\mathrm{Cd}$ on femoral bone structure of adult male rats after a single intraperitoneal administration.

Methods: Ten 4-month-old male Wistar rats were injected intraperitoneally with a single dose of $2 \mathrm{mg} \mathrm{CdCl} / \mathrm{kg}$ body weight and killed $36 \mathrm{~h}$ after the $\mathrm{Cd}$ had been injected. Ten 4-month-old males served as a control group. Differences in body weight, femoral weight, femoral length and histological structure of the femur were evaluated between the two groups of rats. The unpaired Student's t-test was used for establishment of statistical significance.

Results: A single intraperitoneal administration of $\mathrm{Cd}$ had no significant effect on the body weight, femoral weight or femoral length. On the other hand, histological changes were significant. Rats exposed to Cd had significantly higher values of area, perimeter, maximum and minimum diameters of the primary osteons' vascular canals and Haversian canals. In contrast, a significant decrease in all variables of the secondary osteons was observed in these rats.

Conclusions: The results indicate that, as expected, a single intraperitoneal administration of $2 \mathrm{mg} \mathrm{CdCl} / \mathrm{kg}$ body weight had no impact on macroscopic structure of rat's femora; however, it affected the size of vascular canals of primary osteons, Haversian canals, and secondary osteons.
\end{abstract}

\section{Background}

Cadmium $(\mathrm{Cd})$ is considered a dangerous poison for humans and animals. Adverse health effects caused by accidental, spontaneous or experimental exposure to $\mathrm{Cd}$ have led to significant public health concerns [1]. Depending on the dose, route and duration of exposure, $\mathrm{Cd}$ can damage various organs [2]. The kidneys, liver, bones, and respiratory and cardiovascular systems are the most important target organs for Cd toxicity [3].

Changes in bone such as osteopenia, osteoporosis, and osteomalacia, with increased bone fragility and pathological fractures have been noted in humans and experimental animals as a result of exposure to Cd [4-9]. In general, bone toxicity of $\mathrm{Cd}$ can be modulated by both

\footnotetext{
* Correspondence: mmartiniakova@ukf.sk

+ Contributed equally

'Department of Zoology and Anthropology, Constantine the Philosopher

University, Nábrežie mládeže 91, 94974 Nitra, Slovak Republic

Full list of author information is available at the end of the article
}

direct and indirect mechanisms [10,11]. The direct action is associated with altered osteoblastic and osteoclastic activities [12] resulting in decreased bone formation $[13,14]$ and enhanced bone resorption $[15,16]$. The indirect mechanism involves abnormal metabolism of vitamin $\mathrm{D}$ and minerals, mainly calcium $(\mathrm{Ca})$, due to kidney and gastrointestinal tract damages $[17,18]$. Besides interfering with $\mathrm{Ca}$ metabolism, Cd also alters the metabolism of other metals essential for bone health, mainly zinc $(\mathrm{Zn})$, iron $(\mathrm{Fe})$ and copper $(\mathrm{Cu})[19]$. Bonner et al. [20] have reported a decreased concentration of both $\mathrm{Ca}$ and $\mathrm{Zn}$ in the femur of rats after a single injection of $\mathrm{CdCl}_{2}$. However, there have been no reports on changes in bone structure after acute exposure to $\mathrm{Cd}$.

Therefore, the aim of the present study was to determine if there are acute effects of $\mathrm{Cd}$ on femoral bone structure in adult male rats when $\mathrm{Cd}$ is administered intraperitoneally in a single dose.

\section{Biomed Central}




\section{Methods}

Animals

Twenty clinically healthy 4-month-old male Wistar rats (Slovak University of Agriculture, Nitra, Slovak Republic), were divided randomly into two groups of ten animals each. Male rats were used as they are less susceptible than females. The rats were housed individually in plastic cages in an environment maintained at 20$24^{\circ} \mathrm{C}, 55 \pm 10 \%$ humidity. They had access to water and food (feed mixture M3, Bonagro, Czech Republic) ad libitum. Rats of group 1 were injected intraperitoneally with a single dose of $2 \mathrm{mg} \mathrm{CdCl}_{2} / \mathrm{kg}$ body weight (BW) (Reachem, Slovak Republic) and were killed after $36 \mathrm{~h}$. Ten 4-month-old males (group 2) served as an untreated control group and were kept and killed parallel to the $\mathrm{Cd}$ exposed animals. The rats were kept for other investigations (e.g., histological and biochemical analyses) at the Slovak University of Agriculture. In these investigations the acute intraperitoneal administration of $\mathrm{Cd}$ in one dose is generally applied to reveal possible manifestations of $\mathrm{Cd}$ intoxication in different tissues. The present study was performed as an additional investigation focused on bone tissue. All procedures were approved by the Animal Experimental Committee of the Slovak Republic.

\section{Procedures}

At the end of the experiment, all animals were euthanized and weighed. The right femur $(n=20)$ was sampled at necropsy, weighed and measured using analytical scales and a sliding instrument. Specimens were sectioned at the diaphyseal midshaft. Two transversal sections were taken from each femur. The obtained segments were placed in HistoChoice fixative (Amresco, USA). Specimens were then dehydrated in ascending grades of ethanol and embedded in epoxy resin Biodur (Günter von Hagens, Heidelberg, Germany) according to Martiniaková et al. [21]. Histological sections (70-80 $\mu \mathrm{m}$ thick) were prepared with a sawing microtome (Leitz 1600, Leica, Wetzlar, Germany) and affixed to glass slides by Eukitt (Merck, Darmstadt, Germany) as previously described [22]. The qualitative histological characteristics were determined according to the classification systems by Enlow and Brown [23] and Ricqlès et al. [24]. The quantitative variables were assessed using the software Motic Images Plus 2.0 ML (Motic China Group Co., Ltd.) in anterior, posterior, medial and lateral views of thin sections. At least 20 vascular canals of primary osteons were measured in each individual (5 each of anterior, posterior, medial and lateral views). All secondary osteons, which were not in a resorption phase and could clearly be outlined using the Motic Images Plus 2.0 ML software were measured. Magnification of
225 times was used for histomorphometrical measurements. Secondary osteons were distinguished from primary osteons (i.e., primary vascular canals) on the basis of a well defined peripheral boundary (cement line) between the osteon and the surrounding tissue.

\section{Statistics}

Statistical analysis was performed using SPSS 8.0 software. All data were expressed as mean \pm standard deviation (SD). The unpaired Student's t-test was used for establishing statistical significance (significance level of $P<0.05)$ between experimental and control groups.

\section{Results}

Body weight, femoral weight and length did not differ significantly between groups (Table 1 ).

The femora of all rats had the following microstructure in common. An endosteal border was formed by non-vascular bone tissue and/or primary vascular radial bone tissue. Non-vascular bone tissue contained cellular lamellae and osteocytes. Primary and secondary osteons were absent. Primary vascular radial bone tissue created branching or non-branching vascular canals radiating from the marrow cavity. Some primary and secondary osteons were exceptionally found in anterior and posterior views near the endosteal surfaces. In the middle parts of the compact bone, a few primary and secondary osteons were identified. However, dense Haversian bone tissue characterized by dense concentration of secondary osteons was not observed in rats from either group. Finally, the periosteal border was composed of non-vascular bone tissue, mainly seen in anterior and posterior views (Figures 1 and 2). In general, significant differences in qualitative histological characteristics of the compact bone tissue between groups were not observed. No resorption lacunae and/or osteoporotic fractures were found.

Quantitative observations, on the other hand, did differ between the two groups. Data on bone measurements are shown in Tables 2, 3 and 4. The values for the vascular canals of primary osteons were higher in $\mathrm{Cd}$ exposed rats. Significant differences were found for area, perimeter, maximum and minimum diameters of

Table 1 Average body weight, femoral weight and femoral length in rats injected intraperitoneally with a single dose of $2 \mathrm{mg} \mathrm{CdCl} / \mathrm{kg}$ body weight (group 1) and controls (group 2)

\begin{tabular}{ccccc}
\hline & $\boldsymbol{N}$ & $\begin{array}{c}\text { Body weight } \\
(\mathbf{g})\end{array}$ & $\begin{array}{c}\text { Bone weight } \\
(\mathbf{g})\end{array}$ & $\begin{array}{c}\text { Bone length } \\
(\mathbf{c m})\end{array}$ \\
\hline Group 1 & 10 & $430 \pm 55.33$ & $1.12 \pm 0.16$ & $3.95 \pm 0.21$ \\
Group 2 & 10 & $405 \pm 52.65$ & $1.05 \pm 0.17$ & $3.94 \pm 0.09$ \\
T-test & & NS & NS & NS \\
\hline
\end{tabular}

$\mathrm{N}$ : number of rats, NS: non-significant changes 


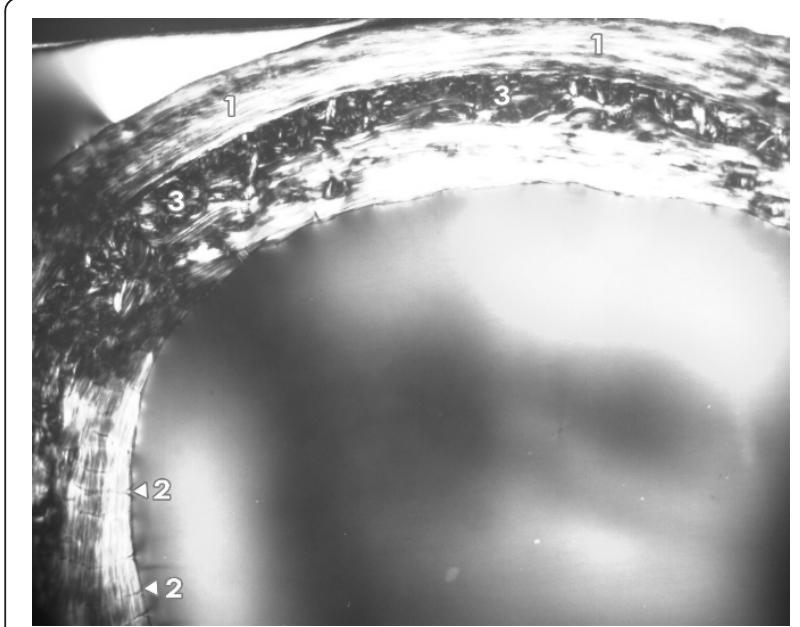

Figure 1 Microscopic structure of femoral bone tissue in rats injected intraperitoneally with a single dose of $2 \mathrm{mg} \mathrm{CdCl} / \mathrm{kg}$ body weight. 1 - non-vascular bone tissue. 2 - vascular canals radiating from marrow cavity. 3 - primary and secondary osteons in middle part of substantia compacta.

primary osteons' vascular canals, i.e. all measured variables. Higher values for all variables of the Haversian canals were also recorded in the rats exposed to $\mathrm{Cd}(P$ $<0.05)$. On the other hand, all variables of the secondary osteons had higher values in rats from the control group. Statistically significant differences were identified for area, perimeter, maximum and minimum diameters of the secondary osteons.

\section{Discussion}

A single intraperitoneal dose has been used to investigate possible acute toxic effects of $\mathrm{Cd}$. The dose was

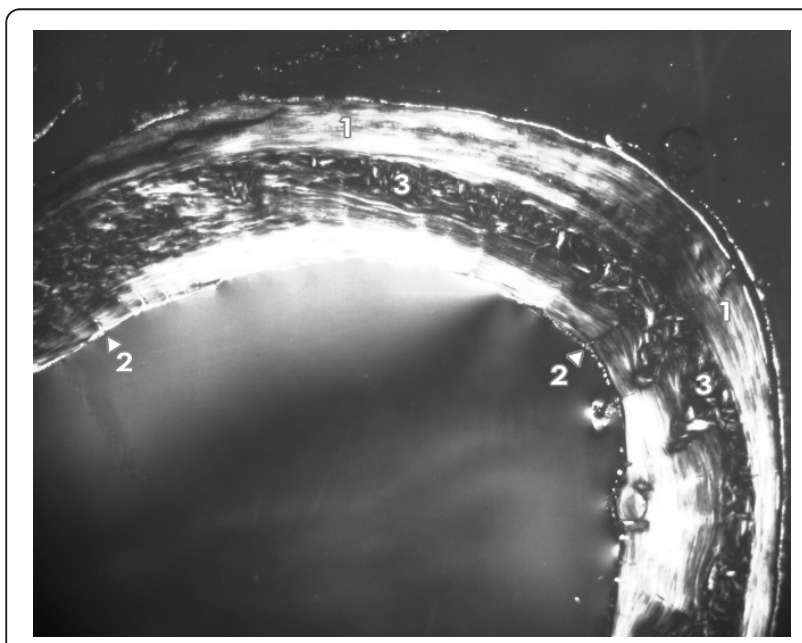

Figure 2 Microscopic structure of femoral bone tissue in rats from the control group. 1 - non-vascular bone tissue. 2 - vascular canals radiating from marrow cavity. 3 - primary and secondary osteons in middle part of substantia compacta. high enough to reach a toxicity level but on the other hand sufficient low to prevent animal mortality. Studies of the Cd effects on bone structure contribute to the knowledge on the mechanisms of $\mathrm{Cd}$ in the organism and the relations between changes found in different organs. Generally, toxic effects of $\mathrm{Cd}$ on bone tissue are studied mainly in relation to the long-term per oral intake of $\mathrm{Cd}$ but it is also interesting to see how $\mathrm{Cd}$ affects bone structure and function after an acute intoxication. To date, only a few studies focusing on the effects of $\mathrm{Cd}$ intoxication on body weight and tissue quantitative changes, (including bone) have been published. With respect to intraperitoneal administration of a low dose of Cd, Comelekoglu et al. [25] found no change in femoral length of adult female rats administered intraperitoneally with $0.5 \mathrm{mg} \mathrm{CdCl}_{2} / \mathrm{kg} \mathrm{BW}$ three times a week for 18 weeks. Similar to this, we did not observe a significant effect from a single intermediate dose of $\mathrm{Cd}$ on femoral length in adult male rats. Also, body weight and femoral bone weight did not differ statistically between the two groups thus demonstrating that a single intermediate dose of $\mathrm{Cd}$ given intraperitoneally has no impact on the macroscopic structure of adult rat's femora.

The results of the qualitative histological analysis correspond to those reported by other researchers working with rats [26-28]. The basic structural pattern of compact bone tissue was non-vascular. In addition, primary vascular radial and/or irregular Haversian bone tissues were observed. However, there was no evidence of true Haversian intracortical bone remodelling. It is generally known that aged rats and mice lack true Haversian cortical bone remodelling but not cancellous bone remodelling [29]. Therefore, some secondary osteons can be observed in long bones near the endosteal border. In our study, the newly formed remodelling units within compact bone originated from the endocortical surface and extended deeply into the underlying compact bone. The same observations were also done by Reim et al. [28] for 13-month-old male rats. We found no resorption lacunae and/or osteoporotic fractures in the Cd exposed rats. This confirms that a single intermediate dose of Cd given intraperitoneally does not cause osteoporosis (e.g., a lot of resorption lacunae, osteoporotic fractures) within 36 hours.

Morphometrical measurements showed a significant increase in area, perimeter, maximum and minimum diameters of the primary osteons' vascular canals, and Haversian canals in group 1 rats. The increase in size of vascular canals (including Haversian canals) may be due to demineralization and bone vascularization. It has been demonstrated that $\mathrm{Cd}$-induced demineralization begins soon after exposure, e.g. within 24 hours of an oral administration and even earlier following 
Table 2 Data on vascular canals of primary osteons

\begin{tabular}{|c|c|c|c|c|c|}
\hline & $N$ & $\begin{array}{l}\text { Area } \\
\left(\mu m^{2}\right)\end{array}$ & $\begin{array}{l}\text { Perimeter } \\
(\mu \mathrm{m})\end{array}$ & $\begin{array}{c}\text { Max. } \\
\text { diameter } \\
(\mu \mathrm{m})\end{array}$ & $\begin{array}{c}\text { Min. } \\
\text { diameter } \\
(\mu \mathrm{m})\end{array}$ \\
\hline $\begin{array}{c}\text { Group } \\
\quad 1\end{array}$ & 395 & $\begin{array}{c}446.26 \pm \\
64.11\end{array}$ & $76.03 \pm 5.92$ & $13.24 \pm 1.54$ & $10.79 \pm 1.15$ \\
\hline $\begin{array}{c}\text { Group } \\
2\end{array}$ & 436 & $\begin{array}{c}393.49 \pm \\
123.04\end{array}$ & $\begin{array}{c}71.58 \pm \\
12.37\end{array}$ & $12.86 \pm 2.67$ & $9.62 \pm 1.68$ \\
\hline \multicolumn{2}{|c|}{ T-test } & $1 \mathrm{vs} .2^{*}$ & $1 \mathrm{vs} .2^{*}$ & 1 vs. $2^{*}$ & $1 \mathrm{vs} .2^{*}$ \\
\hline
\end{tabular}

${ }^{*} P<0.05, \mathrm{~N}$ : number of measured structures

Data on vascular canals of primary osteons in rats injected intraperitoneally with a single dose of $2 \mathrm{mg} \mathrm{CdCl} / \mathrm{kg}$ body weight (group 1, 10 rats) and controls (group 2, 10 rats).

intraperitoneal administration in mice [7]. A dilatation of Haversian canals has also been observed in mice [30] and rats [31] after intraperitoneal administration of $\mathrm{Cd}$. Our results demonstrate that the dilatation can occur after a single intraperitoneal $\mathrm{Cd}$ application. In general, the Haversian canals contain a capillary with a complete endothelial lining, an intact basement membrane, and mesenchymal cells at various stages of differentiation in the extravascular space [32]. Also, it is known that Cd induces hypertrophy of the nucleus and swelling of the cytoplasmatic extension of the endothelial cell [33], which could partially contribute to the increased size of the Haversian canals.

We observed a significant decrease in all variables of the secondary osteons. A reduced size of secondary osteons may be seen in animals with shorter bones [34] but $\mathrm{Cd}$ exposure did not affect bone length in our study. $\mathrm{Cd}$ may replace $\mathrm{Ca}$ in hydroxyapatite crystals $[13,35]$. Blumenthal et al. [13] showed that Cd incorporation into hydroxyapatite introduced little strain in the lattice but resulted in a decreasing $\mathrm{C}$-axis spacing and a corresponding crystal size decrease in the $\mathrm{C}$-axis direction. Hydroxyapatite crystals, as a major mineral component of bones, are aligned with their long axis parallel to the collagen fiber axis [36], creating concentric lamellae of the secondary osteon. Therefore, we speculate that a decreased size of hydroxyapatite crystals

Table 3 Data on Haversian canals

\begin{tabular}{|c|c|c|c|c|c|}
\hline & $N$ & $\begin{array}{l}\text { Area } \\
\left(\mu m^{2}\right)\end{array}$ & $\begin{array}{l}\text { Perimeter } \\
(\mu \mathrm{m})\end{array}$ & $\begin{array}{c}\text { Max. } \\
\text { diameter } \\
(\mu \mathrm{m})\end{array}$ & $\begin{array}{c}\text { Min. } \\
\text { diameter } \\
(\mu \mathrm{m})\end{array}$ \\
\hline $\begin{array}{c}\text { Group } \\
1\end{array}$ & 254 & $\begin{array}{c}468.26 \pm \\
71.44\end{array}$ & $77.66 \pm 6.02$ & $13.43 \pm 1.50$ & $11.14 \pm 1.15$ \\
\hline $\begin{array}{c}\text { Group } \\
2\end{array}$ & 227 & $\begin{array}{c}428.30 \pm \\
75.75\end{array}$ & $74.94 \pm 7.30$ & $13.04 \pm 1.56$ & $10.73 \pm 1.18$ \\
\hline \multicolumn{2}{|c|}{ T-test } & 1 vs. $2^{*}$ & 1 vs. $2^{*}$ & 1 vs. $2^{*}$ & 1 vs. $2^{*}$ \\
\hline
\end{tabular}

${ }^{*} P<0.05, \mathrm{~N}$ : number of measured structures

Data on Haversian canals in rats injected intraperitoneally with a single dose of $2 \mathrm{mg} \mathrm{CdCl} / \mathrm{kg}$ body weight (group 1, 10 rats) and controls (group 2, 10 rats).
Table 4 Data on secondary osteons

\begin{tabular}{|c|c|c|c|c|c|}
\hline & $N$ & $\begin{array}{l}\text { Area } \\
\left(\mu m^{2}\right)\end{array}$ & $\begin{array}{l}\text { Perimeter } \\
\quad(\mu \mathrm{m})\end{array}$ & $\begin{array}{c}\text { Max. } \\
\text { diameter } \\
(\mu \mathrm{m})\end{array}$ & $\begin{array}{c}\text { Min. } \\
\text { diameter } \\
(\mu \mathrm{m})\end{array}$ \\
\hline $\begin{array}{c}\text { Group } \\
1\end{array}$ & 254 & $\begin{array}{c}5284.90 \pm \\
1080.44\end{array}$ & $\begin{array}{c}260.92 \pm \\
27.02\end{array}$ & $45.52 \pm 5.69$ & $36.85 \pm 4.79$ \\
\hline $\begin{array}{c}\text { Group } \\
2\end{array}$ & 227 & $\begin{array}{c}6408.74 \pm \\
1820.98\end{array}$ & $\begin{array}{c}292.98 \pm \\
39.59\end{array}$ & $51.64 \pm 8.17$ & $39.51 \pm 6.20$ \\
\hline \multicolumn{2}{|c|}{ T-test } & $1 \mathrm{vs} .2^{*}$ & 1 vs. $2^{*}$ & 1 vs. $2^{*}$ & 1 vs. $2^{*}$ \\
\hline
\end{tabular}

* $P<0.05, \mathrm{~N}$ : number of measured structures

Data on secondary osteons in rats injected intraperitoneally with a single dose of $2 \mathrm{mg} \mathrm{CdCl} / \mathrm{kg}$ body weight (group 1, 10 rats) and controls (group 2, 10 rats)

could partially contribute to the decreased size of the secondary osteons found in $\mathrm{Cd}$ exposed rats.

The mean diameters of primary osteons' vascular canals, Haversian canals and secondary osteons in rats of the control group were $8.44 \pm 1.11 \mu \mathrm{m}, 9.46 \pm 1.38$ $\mu \mathrm{m}$, and $40.21 \pm 6.62 \mu \mathrm{m}$, respectively. Using the classifications of Rämsch and Zerndt [37] and Gladuhsew [38] these results show that vascular canals of primary osteons and Haversian canals are very short in 4 monthold male rats. Similar results have also been observed in 6 month-old individuals [27].

\section{Conclusions}

Body weight, femoral weight and femoral length were unaffected in adult male rats following a single intraperitoneal administration of $2 \mathrm{mg} \mathrm{CdCl} / \mathrm{kg} \mathrm{BW}$. However, changes in femoral bone histomorphometry were significant as $\mathrm{Cd}$ exposed rats had higher values for area, perimeter, minimum and maximum diameters of primary osteons' vascular canals and Haversian canals while the similar variables for secondary osteons were lower.

\section{Acknowledgements}

This study was supported by the grant KEGA 3/7338/09 (Ministry of Education, Slovakia). This article was written during realization of the project LAGEZ No.26220120051 supported by the Operational Programme Research and Development funded from the European Regional Development Fund. The authors gratefully acknowledge the revision of the English text by Kim Dammers, Konyang University.

\section{Author details}

${ }^{1}$ Department of Zoology and Anthropology, Constantine the Philosopher University, Nábrežie mládeže 91, 94974 Nitra, Slovak Republic. ²Department of Botany and Genetics, Constantine the Philosopher University, Nábrežie mládeže 91, 94974 Nitra, Slovak Republic. 3Johann Friedrich Blumenbach Institute of Zoology and Anthropology, Georg-August University, Bürgerstrasse 50, 37073 Göttingen, Germany. ${ }^{4}$ Department of Veterinary Sciences, Slovak University of Agriculture, Trieda Andreja Hlinku 2, 94976 Nitra, Slovak Republic.

\section{Authors' contributions}

MM was responsible for histological analysis. HC was responsible for macroscopical analysis and photodocumentation of histological sections. RO was responsible for the statistical analysis. BG was responsible for preparation of histological sections. RT was responsible for animal care and sampling of femora. All authors read and approved the final manuscript. 


\section{Competing interests}

The authors declare that they have no competing interests.

Received: 20 January 2011 Accepted: 31 August 2011

Published: 31 August 2011

\section{References}

1. Liu ZP: Lead poisoning combined with cadmium in sheep and horses in the vicinity of nonferrous metal smelters. Sci Total Environ 2003, 309:117-126.

2. Prozialeck WC, Edwards JR, Woods JM: The vascular endothelium as a target of cadmium toxicity. Life Sciences 2006, 79:1493-1506.

3. WHO: Environmental Health Criteria 134, Cadmium Geneva: IPCS; 1992.

4. Wang $H$, Zhu G, Shi Y, Wenig $S$, Jin T, Kong Q, Nordberg GF: Influence of environmental cadmium exposure on forearm bone density. J Bone Miner Res 2003, 18:553-560

5. Brzóska MM, Moniuszko-Jakoniuk J, Jurczuk M, Galazyn-Sidorczuk M, Rogalska J: The effect of zinc supply on cadmium-induced changes in the tibia of rats. Food Chem Toxicol 2001, 39:729-734.

6. Brzóska MM, Majewska K, Moniuszko-Jakoniuk J: Mineral status and mechanical properties of lumbar spine of female rats chronically exposed to various levels of cadmium. Bone 2004, 34:517-526.

7. Bhattacharyya $\mathrm{MH}$ : Cadmium osteotoxicity in experimental animals: mechanisms and relationship to human exposures. Toxicol Appl Pharmacol 2009, 238:258-265

8. Brzóska MM, Majewska K, Kupraszewicz E: Effects of low, moderate and relatively high chronic exposure to cadmium on long bones susceptibility to fractures in male rats. Environ Toxicol Pharmacol 2010, 29:235-245.

9. Brzóska MM, Majewska K, Moniuszko-Jakoniuk J: Weakness in the mechanical properties of the femur of growing female rats exposed to cadmium. Arch Toxicol 2005, 79:519-530.

10. Umemura T, Wako Y: Pathogenesis of osteomalacia in itai-itai disease. $J$ Toxicol Pathol 2006, 19:69-74.

11. Lévesque M, Martineau C, Jumarie C, Moreau R: Characterization of cadmium uptake and cytotoxicity in human osteoblast-like MG-63 cells. Toxicol Appl Pharmacol 2008, 231:308-317.

12. Chen $X$, Zhu G, Gu S, Jin T, Shao C: Effects of cadmium on osteoblasts and osteoclasts in vitro. Environ Toxicol Pharmacol 2009, 28:232-236.

13. Blumenthal NC, Cosma V, Skyler D, Legeros J, Walters M: The effect of cadmium on the formation and properties of hydroxyapatite in vitro and its relation to cadmium toxicity in the skeletal system. Calcif Tissue Int 1995, 56:316-322.

14. Long GJ: The effect of cadmium on cytosolic free calcium, protein kinase C, and collagen synthesis in rat osteosarcoma (ROS 17/2.8) cells. Toxicol Appl Pharmacol 1997, 143:189-195.

15. Miyahara T, Tonoyama H, Watanabe M, Okajima A, Miyajima S, Sakuma T, Nemoto N, Takayama K: Stimulative effect of cadmium on prostoglandin E2 production in primary osteoblastic cells. Calcif Tissue Int 2001, 68:185-191.

16. Regunathan A, Glesne DA, Wilson AK, Song J, Nicolae D, Flores T, Bhattacharyya MH: Microarray analysis of changes in bone cell gene expression early after cadmium gavage in mice. Toxicol Appl Pharmacol 2003, 191:272-293.

17. Aoshima K, Fan J, Cai Y, Katoh T, Teranishi H, Kasuya M: Assessment of bone metabolism in cadmium-induced renal tubular dysfunction by measurements of biochemical markers. Toxicol Lett 2003, 136:183-192.

18. Brzóska MM, Rogalska J, Moniuszko-Jakoniuk J: The concentration of vitamin $\mathrm{D}$ metabolites in the serum of cadmium-exposed female rats. Osteoporosis Int 2003, 14:22-23.

19. Noël L, Guérin T, Kolf-Clauw M: Subchronic dietary exposure of rats to cadmium alters the metabolism of metals essential to bone health. Food Chem Toxicol 2004, 42:1203-1210

20. Bonner FW, King $L$, Parke DV: The acute and subacute effects of cadmium on calcium homeostasis and bone trace metals in the rat. $J$ Inorg Biochem 1981, 14:107-14.

21. Martiniaková M, Omelka R, Grosskopf B, Sirotkin AV, Chrenek P: Sex-related variation in compact bone microstructure of the femoral diaphysis in juvenile rabbits. Acta Vet Scand 2008, 50:15.

22. Martiniaková M, Omelka R, Jančová A, Stawarz R, Formicki G: Heavy metal content in the femora of yellow-necked mouse (Apodemus flavicollis) and wood mouse (Apodemus sylvaticus) from different types of polluted environment in Slovakia. Environ Monit Assess 2010, 171:651-660.

23. Enlow DH, Brown SO: A comparative histological study of fossil and recent bone tissues. Part I. Texas J Sci 1956, 8:405-412.

24. de Ricalès AJ, Meunier FJ, Castanet J, Francillon-Vieillot H: Comparative microstructure of bone. In Bone 3, Bone Matrix and Bone Specific Products. Edited by: Hall BK. Boca Raton: CRC Press; 1991:1-78.

25. Comelekoglu U, Yalin S, Bagis S, Ogenler O, Sahin NO, Yildiz A, Coskun B, Hatungil R, Turac A: Low-exposure cadmium is more toxic on osteoporotic rat femoral bone: mechanical, biochemical, and histopathological evaluation. Ecotox Environ Safety 2007, 66:267-271.

26. Enlow DH, Brown SO: A comparative histological study of fossil and recent bone tissues. Part III. Texas J Sci 1958, 10:187-230

27. Martiniaková $M$, Grosskopf $B$, Vondráková $M$, Omelka R, Fabiš M Observation of the microstructure of rat cortical bone tissue. Scripta medica 2005, 78:45-50.

28. Reim NS, Breig B, Stahr K, Eberle J, Hoeflich A, Wolf E, Erben RG: Cortical bone loss in androgen-deficient aged male rats is mainly caused by increased endocortical bone remodeling. J Bone Miner Res 2008, 23:694-704.

29. Erben RG: Trabecular and endocortical bone surfaces in the rat: modeling or remodeling? Anat Rec 1996, 246:39-46.

30. Habeebu SS, Liu J, Liu Y, Klaassen CD: Metallothionein-null mice are more susceptible than wild-type mice to chronic $\mathrm{CdCl}_{2}$-induced bone injury. Toxicol Sci 2000, 56:211-219.

31. Katsuta O, Hiratsuka H, Matsumoto J, Iwata H, Toyota N, Tsuchitani M, Umemura T, Marumo F: Cadmium-induced osteomalacic and osteopetrotic lesions in ovariectomized rats. Toxicol Appl Pharmacol 1994, 126:58-68.

32. Takahashi S, Sugimoto M, Kotoura Y, Sasai K, Oka M, Yamamuro T: Longterm changes in the Haversian systems following high-dose irradiation. $J$ Bone Joint Surg 1994, 76-A:722-738.

33. Haffor AS, Al-Dokhi OA: Endothelial cell toxicity of cadmium: transmission electron microscopy examination. Pak J Biol Sci 2004, 7:782-788.

34. Jowsey J: Studies of Haversian systems in man and some animals. J Anat 1966 100:857-864.

35. Brzóska MM, Moniuszko-Jakoniuk J: Bone metabolism of male rats chronically exposed to cadmium. Toxicol App Pharmacol 2005, 207:195-211.

36. Boskey AL: The organic and inorganic matrices. In Bone tissue engineering. Edited by: Hollinger JO, Einhorn TA, Doll BA, Sfeir C. Boca Raton: CRC Press; 2005:91-123.

37. Rämsch R, Zerndt B: Comparative investigation of Haversian canals between humans and farm animals [in German]. Arch Kriminol 1963, 131:74-87.

38. Gladuhsew JM: Problems of the histological investigation of the bone in forensic medicine. Sudebno Med Exp 1964, 7:23-26.

doi:10.1186/1751-0147-53-49

Cite this article as: Martiniaková et al:: Effects of a single intraperitoneal administration of cadmium on femoral bone structure in male rats. Acta Veterinaria Scandinavica 2011 53:49

\section{Submit your next manuscript to BioMed Central and take full advantage of:}

- Convenient online submission

- Thorough peer review

- No space constraints or color figure charges

- Immediate publication on acceptance

- Inclusion in PubMed, CAS, Scopus and Google Scholar

- Research which is freely available for redistribution 